This item was submitted to Loughborough's Research Repository by the author.

Items in Figshare are protected by copyright, with all rights reserved, unless otherwise indicated.

\title{
Mathematics teacher educator learning and development
}

PLEASE CITE THE PUBLISHED VERSION

https://www.sensepublishers.com/

PUBLISHER

(c) SensePublishers

VERSION

AM (Accepted Manuscript)

LICENCE

CC BY-NC-ND 4.0

REPOSITORY RECORD

Jaworski, Barbara. 2019. "Mathematics Teacher Educator Learning and Development". figshare. https://hdl.handle.net/2134/8800. 
This item was submitted to Loughborough's Institutional Repository (https://dspace.lboro.ac.uk/) by the author and is made available under the following Creative Commons Licence conditions.

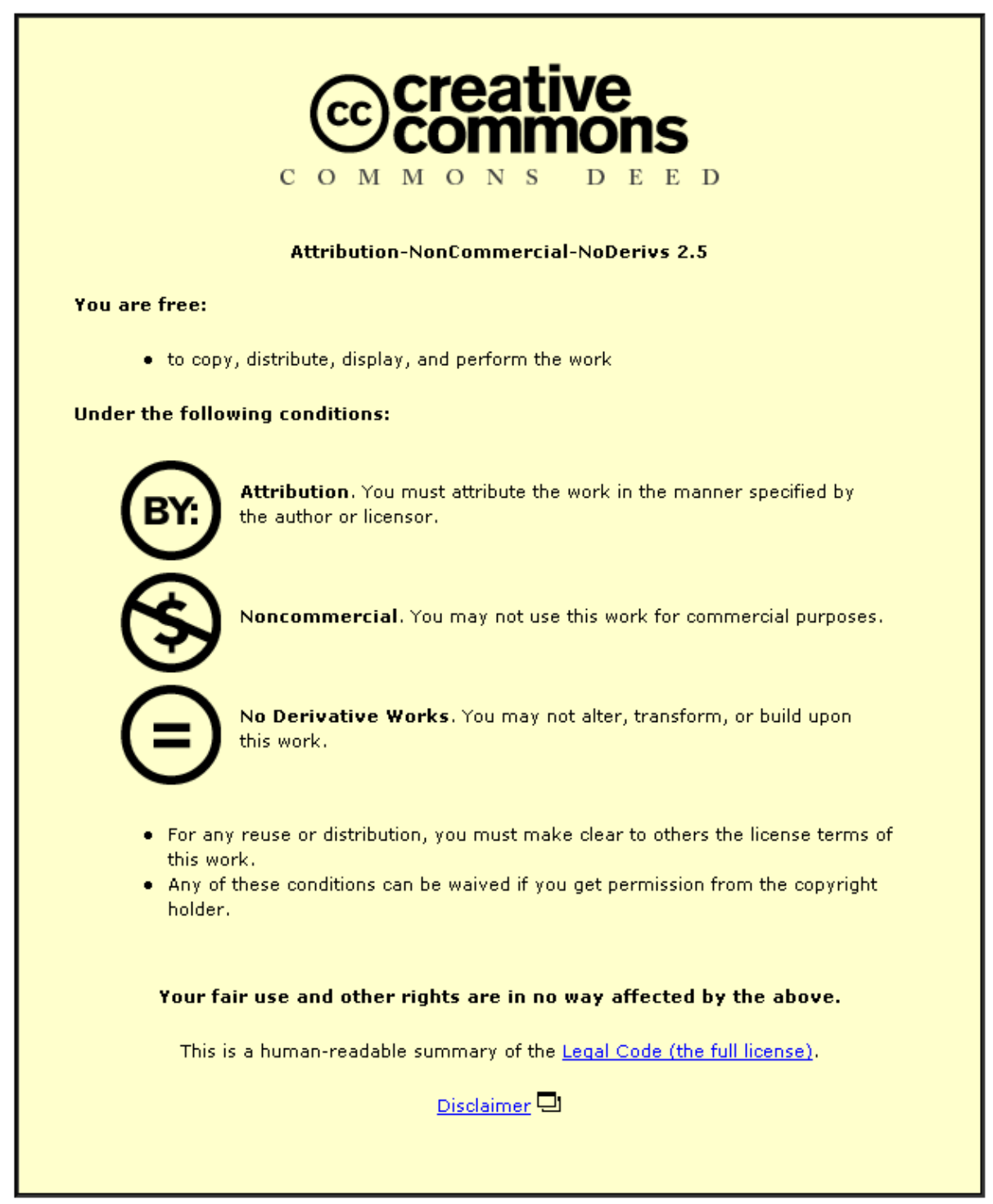

For the full text of this licence, please go to: http://creativecommons.org/licenses/by-nc-nd/2.5/ 
BARBARA JAWORSKI

\section{MATHEMATICS TEACHER EDUCATOR LEARNING AND DEVELOPMENT}

This chapter serves as an introduction to Volume 4 as a whole. The stated aim of the volume is to open up the practice of mathematics teacher educators to scrutiny and critique: locating our practices internationally, identifying issues both local and global, and seeing ourselves as practitioners alongside teacher practitioners with whom we work. The chapter begins with a brief discussion of mathematics teacher educator knowledge, learning and development, locating this both historically and theoretically. It goes on to address the three sections: Challenges to and theory in mathematics teacher education; Reflection on developing as a mathematics teacher educator; Working with prospective and practising teachers: what we learn; what we come to know; and presents a short account of each chapter. The chapter ends with a vision of teacher educator practice for the future.

Mathematics teacher educators are professionals who work with practising teachers and/or prospective teachers to develop and improve the teaching of mathematics. They are often based in university settings with academic responsibilities. The qualities required of teacher educators are in many respects the same as those required of mathematics teachers. They need to know mathematics, pedagogy related to mathematics, mathematical didactics in transforming mathematics into activity for learners in classrooms, elements of educational systems in which teachers work including curriculum and assessment, and social systems and cultural settings with respect to which education is located. In addition they need a knowledge of the professional and research literature relating to the learning and teaching of mathematics, knowledge of theories of learning and teaching, and knowledge of methodologies of research that inquires into learning and teaching in schools and educational systems. In many cases mathematics teacher educators have been mathematics teachers themselves and bring a profound professional experience to their work with teachers. Such experience brings with it credibility: teachers can see that teacher educators have themselves grappled with the practical realities of classroom settings and the systemic demands that teachers face. Educators by the very nature of their roles in higher education do not know intimately the students with whom teachers work or the particularities of the schools where teaching takes place. Teachers are the ones with profound knowledge in these areas, although they might reasonably expect that educators have past experiences that enable an empathetic appreciation of the day to day issues teachers face. In a synthesis of the theoretical and the practical, MTE's

Jaworski, B., \& Wood, T. (Eds.) (2008). International handbook of mathematics teacher education: Vol. 4 The mathematics teacher educator as a developing professional. Rotterdam, The Netherlands: Sense Publishers. 00-00. (C) 2005 Sense Publishers. All rights reserved. 
develop knowledge of how teaching and new practices are learned, how such learning occurs, and the associated pitfalls and this parallels teachers knowing and sensitivity to students learning. The diagram in Figure 1 represents the relationships I have just sketched.

From the perspective of this diagram which is necessarily simplistic, educators draw on their knowledge in A and B to promote growth of knowledge in B and C. Location of their own knowledge in $\mathrm{B}$ ensures a recognition that educators are learning as well as teachers. However, the direction of influence from A to B and C is not the only one we need to consider: we need to be aware of the mutual and reciprocal influences of knowledge in practice of educators and teachers in B and $\mathrm{C}$, a complexity that is only implicit in this diagram. The knowledge of prospective teachers is also located in $\mathrm{B}$ and $\mathrm{C}$ and, for prospective teachers, both educators and practising teachers are educators. This diagram serves to introduce

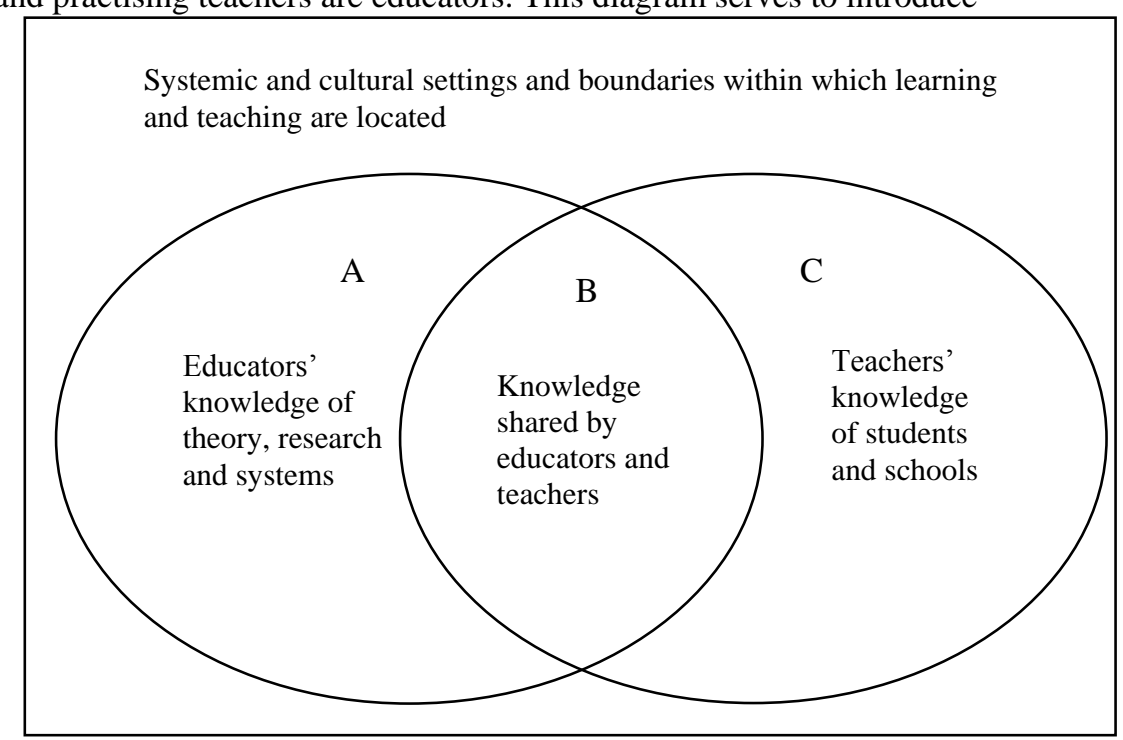

Figure 1: Knowledge in teacher education

the complexity of factors and issues that this volume addresses. I return to this diagram in Chapter 18, seeking to synthesise from the collection of chapters.

Teacher educators have responsibility towards development of knowledge in teaching. This might be seen as developing the knowledge of teachers - teaching teachers - and certainly this is part of the picture. After six years of editing the Journal of Mathematics Teacher Education (JMTE), I have read a considerable number of papers from teacher educators who have researched their own programmes of teaching teachers, and reported the outcomes. Such papers report from programmes for prospective teachers and from programmes for practising teachers; programmes that take several years to complete, or short courses or 
summer institutes; programmes that encourage teacher reflection, teachers' involvement in research, and extensive use of technology. In most such papers, findings report outcomes for teachers from engagement in the programme and raise issues for teachers or for teacher education more generally. Some papers advise other teacher educators as to approaches that can achieve certain outcomes or of where to be aware of particular issues. A very few papers reflect critically on the teacher education process, on what teacher educators themselves learn from engaging in teacher education, through reflecting on their own practice, and through research into the programmes they design and lead. And even fewer papers report on the learning of the teacher educator or on programmes designed to educate educators. Authors in this last category are highly represented within the chapters of this volume.

In 1999, in a chapter in an edited volume on Mathematics Teacher Education (Jaworski, Wood and Dawson), Sandy Dawson wrote as follows:

There seems to be a culture of mathematics inservice education hinted at in the programmes described earlier in the book. Reading between the lines of those descriptions one could argue that this manifestation of inservice culture seems to have the following basic principle: there is something wrong with mathematics teaching world-wide and we, as mathematics educators, must fix it. Many mathematics teachers have bought into this culture. Such teachers seem to be seeking new ways to fix their practice. But this places mathematics teachers in a relationship of co-dependence with mathematics teacher educators. Mathematics teachers need someone to fix them, and mathematics teacher educators need someone to fix. The two groups seem made for each other (p. 148).

The heavy irony here was deliberate. It suggested that many programmes were designed to pass on knowledge and expertise from the educator to the teacher.

In the same volume, Terry Wood and I synthesized themes and issues from papers in the volume, and reported that many papers claimed to ground programmes in a constructivist theory of knowledge and learning. Cutting through the complexities, such perspectives eschewed a transmissive approach to teaching and sought centrality of the learner in the learning process: as with mathematics teaching in classrooms, so with the teaching of mathematics teachers (see pages 138-139). Papers spoke of “"challenging teachers; conceptions' and providing opportunities for teachers to reflect on and possibly change these conceptions" (Amit \& Hillman, 1999. p. 18). Other papers spoke of teachers: "He considers that materials allow ... the construction of pupils' own reasoning" (Serrazina \& Loureiro, 1999, p. 53). Carter and Richards (1999, p. 69) spoke of their inquiry approach being "framed in a constructivist epistemology", indicating a focus on "sense making, building up of one's ideas". Irwin and Britt (1999, p.91) set out in their teacher education programme to test a suggestion that "if teachers were to develop a new teaching methodology compatible with a constructivist view of learning, the professional development itself should be constructivist in nature". On the face of it, such programmes might be seen as countering what Dawson 
expresses as "designed to pass on knowledge and expertise from the educator to the teacher". The philosophy was rather to engage teachers in activity through which they could develop their knowing in the domains detailed above.

The book referred to above resulted from a working group of 10 years' duration at yearly Psychology of Mathematics Education (PME) conferences (1986-1996). The mathematics education literature in those years was theoretically dominated by constructivist theory, evidenced by seminal work including Cobb, Wood and Yackel, 1990; Confrey, 1990; Davis, Maher and Noddings, 1990; Glasersfeld, 1987; Steffe and Thompson, 2001. It seemed unsurprising, therefore, at the time, that so many papers presented a constructivist perspective on teaching-learning at both classroom and teacher education levels. What is perhaps surprising was that very few papers at this time challenged the over-riding constructivist perspective or offered alternative ways to theorise teacher education. While conceptualising learning through constructivist theory, teaching and teacher education was premised on educators creating programmes in which teachers would in a sizeable variety of ways encourage their pupils' construction of mathematics. The pedagogies that this should involve were the focus of many of the programmes reported; inculcating or fostering such pedagogies was the aim of the programmes. The successes of, and/or issues raised by such pedagogies were largely reported without a concomitant questioning of the underlying rationale to which the irony of Dawson above draws attention.

Almost a decade later, JMTE still receives many papers in the same vein. However, there has been a shift. One obvious difference is that constructivism has moved from a largely cognitive, psychological focus to take into account social contextual and institutional factors, often relating to the work of Vygotsky (e.g. Cobb, 1994; Confrey 1995). In parallel, sociocultural theories, rooted in the work of Vygotsky and followers have become better known and understood in mathematics education, with a challenge, implicit or explicit, to constructivism (e.g., Forman \& Ansell, 2001; Lerman 1996), and social, cultural, political and policy issues have become more evident in the mathematics education literature (e.g., Cooper \& Dunne, 2000; Vital \& Valero, 2003; Zevenbergen, 2001), perspectives of teacher educators have moved into more social frames (e.g., Blanton, Westbrook \& Carter, 2005; Goos, Galbraith \& Renshaw, 1999) with recognition also of the wider influences of system and society (Krainer, 2006; Lachance \& Confrey, 2003).

While theoretical issues such as these are relatively obvious, the main difference that I would point to is less easy to articulate. It concerns a shift in tone and nuance in the ways educators write about educating teachers. There is less of a surety of models of practice that educators promote with teachers and much more a sense of uncertainty. With this uncertainty comes, almost paradoxically, a strength of purpose, new ways of speaking about mathematics teacher education, and new paradigms of practice. These build on notions of reflection for both teachers and teacher educators, on teacher-as-researcher and simultaneously educator-asresearcher positions, and on growing recognitions of epistemology, of complexity 
and the importance of not trying to oversimplify (e.g., Brown and Coles, 2000; Davis, Simmt \& Sumara, 2006; Potari \& Jaworski, 2002; Steinbring, 1998).

The chapters in this volume have all been written, by invitation, for this volume. So, with regard to historical development, they are state of the art. Some authors have written before about teacher educator development; others are writing about it explicitly for the first time, albeit drawing on a wide experience of research in and critical analysis of teacher education programmes. An aim of this volume is to open up the practice of mathematics teacher educators to scrutiny and critique: locating our practices internationally, identifying issues both local and global and seeing ourselves as practitioners alongside the teacher practitioners with whom we work. Roles of teacher educators and the dilemmas, issues and anomalies we face are central to this volume.

The volume is organised into four sections.

- Challenges to and theory in mathematics teacher education;

- Reflection on developing as a mathematics teacher educator;

- Working with prospective and practising teachers: what we learn; what we come to know;

- Synthesis.

\section{CHALLENGES TO AND THEORY IN MATHEMATICS TEACHER EDUCATION}

The six chapters in this section take a broad focus within the discipline of mathematics teacher education, focusing particularly on challenges to, or within, the discipline or on particular theoretical perspectives, or both. Where they draw on particular programmes or initiatives, it is largely to exemplify more general theories, issues or perspectives. Theoretical perspectives differ across these papers.

The first chapter, written by Martin Simon, takes a critical look at the challenges facing mathematics teacher education and hence mathematics educators. Coming from a cognitive constructivist perspective, and focusing on "courses and workshops for teachers in which teacher educators aim to promote particular mathematical and pedagogical concepts, skills and dispositions", Martin highlights four key areas of research-based knowledge that he sees as currently insufficient for teacher education efforts that promote envisaged reforms. He roots his arguments in perspectives of teachers and educators that are perception-based or conception-based. In the former, perceptions of how things are for the teacher or educator dominate what is possible in fostering the learning of others. In the latter, teachers or educators struggle to address how other learners develop concepts and to know the prior concepts on which new knowledge is to be built. The rationale here is psychological drawing on Piaget's concepts of assimilation and reflective abstraction. The chapter opens up the conceptual frame in mathematics teacher education and challenges teacher educators to be aware of psychological (under)currents in their development of educational programmes and design of research.

From a psychological perspective, cognitive and affective, John Mason focuses on three As, attention, awareness and attitude, in addressing learners', teachers' 
and teacher educators' interactions with each other and with their substance of learning. He uses a metaphor of human psyche as chariot to write about the human body (chariot), senses (the horses), cognition/awareness (the driver), imagery (the reins) and so on. He draws attention to the act of drawing attention to, recognising that, in any learning-teaching moment, attention of learner and teacher may be quite different signifying different awarenesses. A teachers' awareness in discipline can allow the teacher to direct students' attention to key aspects of the action in which they engage through a careful choice of tasks and tools; in doing so the teacher has to be aware of students' awareness in the action of engaging with mathematics. The complexity of these states of awareness is compounded when we consider the teacher educator working with teachers to draw-attention-to/bring-toawareness aspects of discipline including those of attention and awareness. John refers to these educative stances as second and third order disciplines.

Ruhama Even writes about the education of educators of practising teachers with particular reference to a unique programme, Manor, in Israel. She draws attention to both the lack of attention in the literature to the education of teacher educators and to the (concomitant) lack, internationally, of such education programmes. Three problematic aspects are defined as: almost no research on the education of mathematics teacher educators; the ill-defined nature of the field of educating practicing mathematics teachers; and a lack of information on the practice of mathematics teacher educators working with practicing teachers. Ruhama uses the term "knowtice" to capture theoretically a unique blend of knowledge and practice, a pragmatic view, in the educative process using the Manor programme as a paradigmatic example. She traces elements of conceptualization, recruitment and considerations of curriculum and practice, the latter both in seminars for prospective teacher educators in educative settings and in practice in settings involving activity with practicing teachers. The meta-layers of educators educating educators are clearly distinguished. The chapter ends with a focus on future needs with attention to key research questions relating to the nature of the field, its knowledge base and the kinds of practices it encompasses.

Merrilyn Goos's chapter focuses on the use of sociocultural theories to analyse, explain and promote development in mathematics teacher education. Within a Vygotskian framework, she focuses particularly on the work in Valsiner in three developmental "zones", Zone of Free Movement (ZFM), Zone of Promoted Action (ZPA) and Zone of Proximal Development (ZPD), and refers briefly to studies in mathematics teacher education that have used such theory in their analyses. She draws on her own research to offer analyses of the learning of two beginning teachers using the inter-relationships in these zones. Relationships between the zones enable a holistic addressing of teachers' settings, actions and beliefs and ways in which these relationships might change over time across a variety of contexts. Merrilyn extends zone theory to situations and roles of the mathematics teacher educator, suggesting that zone theory can offer a means to analyse, explain and promote the activity of the mathematics teacher educator researcher.

The focus of Orit Zaslavsky's chapter is on the design and use of tasks to promote learning of teachers and concomitantly that of teacher educators, relating 
implicitly to the influence of design theory in the learning sciences (e.g. Kelly 2003; Wood and Berry, 2003). Her chapter begins with consideration of seven broad themes that address qualities and kinds of competence and knowledge that mathematics teacher education seeks to promote in prospective and practising teachers in a broad sense. Within this panorama she identifies the role of carefully designed tasks to mediate between on the one hand facilitating teacher learning and on the other researching teacher practice and knowledge. The seeking for, design and use of tasks which have the aim of promoting teachers' learning is a formative process for the teacher educator from which knowledge and awareness develop. Orit draws on her own experience in designing a task for teachers that went through several metamorphoses or iterative cycles through research into its use and the feeding back of knowledge gained in practice to the design process. The increasing sophistication of the task mirrored the growth of understanding of the educators, analysed with respect to the seven themes. The chapter ends by considering the demands on teacher educators as facilitators of teacher learning.

The final chapter in this section, by Olive Chapman, offers a review of a selected set of papers focusing on teacher educators' programmes for prospective teachers that take a cognitive perspective. The review addresses what we can learn as teacher educators from what is reported in this research, categorising the range of factors under broad headings of characteristics of instructional practices, and characteristics of learning outcomes. These instructional practices and learning outcomes include both teacher working with classroom student as learner of mathematics and teacher educator working with prospective teachers as learners of mathematics teaching. Olive points out that the reports from these studies present the outcomes of the research as sources of learning for those reading the reports rather than for those writing the reports. In other words, teacher educators as researchers take mainly an outsider position in reporting their research; only a few reflect the insider position of teacher educator learning and its impact on their practice.

\section{REFLECTION ON DEVELOPING AS A MATHEMATICS TEACHER EDUCATOR}

Consideration of insiders and outsiders takes us neatly into the second section of this volume. Here the focus is overtly on the mathematics teacher educator as an insider researcher developing practice through research in and on practice. The chapters here reflect personal journeys in mathematics teacher education through which the teacher educators themselves develop their professional practice.

The first chapter, by Ron Tzur, picks up an earlier story (Tzur, 2001) of Ron's own development as a Mathematics Teacher Educator and expands it theoretically to conceptualise and characterise a construct called PALP (Profound Awareness of the Learning Paradox). The learning paradox (Bereiter, 1985) concerns the need for a conceptual structure at least as complex as the concept to be learned, posing a serious challenge for the intuitive teaching of reform-minded teachers. PALP leads mathematics teachers or teacher educators to construct tasks that might seem counter-intuitive to those lacking such awareness, but which result in learning of 
desired concepts by the students or teachers who are the focus of the tasks. Through three cases in which he worked with teachers in designing tasks for students, Ron charts his own developing awareness of addressing the learning paradox, and synthesises five 'capacities' that serve as goals for mathematics teacher educators' development.

Razia Fakir Mohammad writes about her own personal development as a teacher educator in Pakistan, working with teachers in Pakistani schools and in developmental courses at her university. Starting from her personal philosophy for education, a belief in co-learning as an approach to working with teachers, Razia describes episodes from her work that raise issues for her moral and ethical stance and create dilemmas in her practice. We see the Pakistani context itself with its hierarchies of respect and authoritarian school systems offering major challenges to her work as a teacher educator. Through her interactions with teachers in which she struggles with her own aims and beliefs related to the teachers themselves and the students they have responsibility to teach, Razia charts a personal growth of understanding for dealing with contradictory forces and living with the outcomes. She ends with a theoretical synthesis to generalise this process.

Konrad Krainer also offers a personal account of his development as a mathematics teacher educator, juxtaposing it with a model of growth and development within a mathematics education discipline. Using a model of seven nested domains with mathematics at the centre, he traces both his own development and a (historical) development of research in mathematics education. Here we see the focus changing from early studies related to mathematical content to current focuses on the roles of teacher educators and development of mathematics learning and teaching within school and educational systems. The growth of individuals, mathematics teachers and teacher educators, can have only a minor influence so long as perspectives remain at local levels. Konrad offers a powerful thesis that development will only be sustainable with an attention to the wider systems, structures and populations within the societies that mathematics serves. As long as mathematics remains unknown, elitist, separatist, feared by significant members of society and education, it can not become accessible to all, nor bring its powerful potential for communication to fruition.

Simon Goodchild speaks of achieving "good research". This sits alongside aims for achieving better mathematics teaching and learning. Simon's own biographical development shows a progression from research characterised as "data extraction" - extracting and analysing data from research settings with minimal involvement of the participants in those settings, the teacher and students - to developmental research in which all participants are engaged fundamentally in the research and influenced by this involvement to improve practice. As an example, he focuses on a particular large-scale research project in Norway in which didacticians and teachers worked together to inquire into practices and processes of teaching mathematics in school classrooms and the associated learning outcomes for pupils. Simon uses this project to illustrate key facets of a developmental research process and relates these to principles in critical theory through which emancipation and empowerment are theoretical goals and practical gains. 


\section{WORKING WITH PROSPECTIVE AND PRACTISING TEACHERS: WHAT WE LEARN; WHAT WE COME TO KNOW.}

In this section the focus moves more overtly into the practice field, albeit with a continuing theoretical dimension. Here we find commentary on programmes and practices and on the perspectives and rationalisations that underpin them. Practices include programmes for prospective or practising teachers and address forms of knowledge, professional competencies and dilemmas of practice that challenge teacher educators in their professional lives.

Christer Bergsten and Barbro Grevholm identify a key concept, which they call the 'didactic divide', that separates teachers' learning in theoretical contexts based on their university study from that in practically-based contexts relating to classrooms and pupils. Their chapter traces in the literature a progression from competency models relating to teacher knowledge and competency, through recognition of the interactivity of teachers and teacher educators in teacher education programmes to consideration of the practices of teachers educators and their associated knowledge. The complexity of educational processes is emphasised throughout with attention to the problems of fragmentation and desire for holistic approaches. The chapter presents a range of approaches through which power differentials are reduced and learning of pupils, prospective teachers, practicing teachers and teacher educators take place within mutually sustaining environments that present opportunities to overcome the didactic divide.

Amy Roth McDuffie, Corey Drake and Beth Herbel-Eisenmann report on their collaboration as a threesome in reflecting on and analysing their design and teaching of mathematics methods courses for prospective elementary teachers. These are typical of such courses across the United States and thus fit a cultural stereotype, subject to institutional and systemic factors in the US educational system. The three MTEs compared and contrasted their design and thinking about the courses, reflecting on both the material of the courses and the motivational thinking that underpinned activity and action. As well as presenting a detailed account of what they do, how they do it and the associated reasons related to research on prospective elementary teacher development, the three MTEs acknowledge their own learning through collaborative preparation of this chapter. Particularly they characterise the developmental process in learning to teach as "teaching as learning in practice" and speak of using inquiry approaches throughout their practice with prospective teachers. Thus as they encourage prospective teachers to learn through inquiry into the learning of their students of mathematics in classroom settings, the three MTE's inquire into their own practice and become more knowledgeable about their activity and its development.

Victoria Sánchez and Mercedes Garcia use the idea of 'dilemmas' in education to reflect on and analyse their design and development of a teacher education programme for prospective primary teachers. They define a dilemma as denoting a potential action and opting for a practical strategy to manage inconsistencies between beliefs and practice. The dilemmas they negotiate take them deeply into consideration of three layers of design and development in their programme: 
'given' by the institution versus 'chosen' by the teacher educator; adapting from other teacher education programmes versus building on research; and problems to be handled versus problems for research. In discussing these three dilemmas, they delve deeply into the literature in mathematics teacher education, searching what others have written for insights into and support for their own trajectories of thinking. We see in their account a broad consideration of theory and practice internationally as it is represented in this literature. Finally they come through the account of design and development of a programme, and the many choices it has encompassed to reflection on their own learning as educators in a mathematical context for primary teachers. This returns to theoretical perspectives in their account of design particularly those of community of practice, extending now to community of inquiry as they examine their own learning through inquiry in their developmental research process.

The chapter by Pat Perks and Stephanie Prestage focuses on tools for learning, including the learning of pupils, prospective teachers and their own learning as teacher educators at secondary level. In these three layers, learning in an inner layer generates the tools for the next outer layer. Within a Vygotskian theoretical frame, these authors recognise the teacher/educator role in promoting scientific concepts and simultaneously nurturing spontaneous concepts. Tasks and associated activity are designed to encourage generation of labels to describe key elements of pedagogy which can then be available for use in the classroom or university seminar. Pat and Stephanie reflect on their own use of tools, particularly the tool of writing, in which they encapsulate and synthesise concepts that are in process of formation.

Paola Sztajn writes about 'caring' relations. Drawing on the work of Nel Noddings, she analyses the role of teacher educator as carer for the teachers with whom he or she works. Importantly, she makes clear that the caring relationship, for its success, depends on the foundational human quality of reciprocity between the carer and the cared-for: this acknowledges an overt recognition, by the caredfor, of the caring approach such that a reciprocal caring emerges. Offering three examples from stages in her own development, working with practising teachers in a variety of settings and contexts, Paola shows how caring relationships can differ and how the nature of the (reciprocal) relationship affects the outcomes of the mutual process. The apparent contradiction of carer putting aside own goals to facilitate goals of the cared-for resulting in achievement of the carer's own goals is carefully analysed.

The final chapter in this section is written by Sandy Dawson who, following an extensive career as mathematics teacher educator, has recently spent eight years working with teachers, teacher educators and the people of the island territories widely spread across the Pacific Ocean. Building on earlier work with First Nations communities in Canada, Sandy discusses his educative approach on the building of mutual respect and trust between peoples. The chapter draws on episodes from this work to show how peoples from very different cultures come together to learn mathematics and teaching mathematics, and how Sandy as a teacher educator came to know and understand how to generate trust and respect in relation to new and 
strange customs. The chapter introduces readers to the practice of the "wisdom circle" and the theory of "subtle" as underpinning the growth of knowledge in overtly conscious cultural settings. This chapter, together with the ones from Razia Fakir Mohammad and Paula Sztajn, emphasises the social, contextual and affective sides of teacher education and the complex functionings of, and challenges for, a mathematics teacher educator alongside teachers as partners in the educative process.

\section{SYNTHESIS}

The final section of the volume is one of synthesis and includes just one chapter which I have written. Here, I have taken on the demanding and (for me) exciting challenge of synthesising from the richness and diversity of ideas as I have seen them to emerge through my reading and re-reading of the chapters in this volume. In these chapters we see both reinforcing commonality and differences in ways of seeing issues, particularly in terms of theoretical perspectives. It has seemed important to me to emphasise the complexity within our field and ways in which the theoretical perspectives help us to explain and tackle issues and tensions. The theme of the final chapter, that emerges from this process, is development of the mathematics teacher educator and its relation to teaching development. It sees teachers and educators both as learners and researchers in practice and suggests that co-learning between teachers and educators can be seen as the way ahead for developing mathematics teacher education practice. I see this volume not only as the first collection of writings concerning the mathematics teacher educator as a developing professional but also as an inspiration for further seriously focused work in this area.

\section{REFERENCES}

Amit, M., \& Hillman, S. W. (1999). Changing mathematics instruction and assessment: Challenging teachers' conceptions. In B. Jaworski, T Wood, \& S. Dawson (Eds.), Mathematics teacher education: Critical international perspectives (pp. 17-25). London: Falmer Press.

Blanton, M. L., Westbrook, S., \& Carter, G. (2005). Using Valsiner's zone theory to interpret teaching practices in mathematics and science classrooms. Journal of Mathematics Teacher Education, 8, 533.

Brown, L., \& Coles, A. (2000). Complex decision-making in the classroom: The teacher as an intuitive practitioner. In T. Atkinson \& G. Claxton (Eds.), The intuitive practitioner: On the value of not always knowing what one is doing (pp. 165-181). Buckingham: Open University Press.

Carter, R., \& Richards, J. (1999). Dilemmas of constructivist mathematics teaching: Instances from classroom practice. In B. Jaworski, T Wood, \& S. Dawson (Eds.), Mathematics teacher education: Critical international perspectives (pp. 69-77). London: Falmer Press.

Cobb, P. (1994). Where is the mind? A coordination of sociocultural and cognitive constructivist perspectives. Educational Researcher, 23, pp13-23.

Cobb, P., Wood, T., \& Yackel, E. (1990). Classrooms as learning environments for teachers and researchers. In R. B. Davis, C. Maher, \& N. Noddings (Eds.), Constructivist views on teaching and 


\section{BARBARA JAWORSKI}

learning mathematics (pp. 125-146), Journal for Research in Mathematics Teacher Education, Monograph Series, No. 4. Reston, VA: National Council of Teachers of Mathematics.

Confrey, J. (1990). What constructivism implies for teaching. In R. B. Davis, C. Maher, \& N. Noddings (Eds.), Constructivist views on teaching and learning mathematics (pp. 107-124), Journal for Research in Mathematics Teacher Education, Monograph Series, No. 4. Reston, VA: National Council of Teachers of Mathematics.

Confrey, J. (1995). How compatible are Radical Constructivism, Sociocultural Approaches, and Social Constructivism? In L. P. Steffe \& J. Gale (Eds.). Constructivism in education. Hillslade, NJ: Lawrence Erlbaum Associates.

Cooper, B., \& Dunne, M. (2000). Assessing children's mathematical knowledge: Social class, sex and problem solving. Buckingham, UK: Open University Press.

Davis, B., Simmt, E., \& Sumara, D. (2006). Mathematics-for-teaching: The cases of multiplication and division. In J. Novotná, H. Moraová, M. Krátká, \& N. Stehliková (Eds.), Proceedings of the 30th Conference of the International Group for the Psychology of Mathematics Education (Vol. 2, pp. 385-392). Prague, Czech Republic: Charles University.

Davis, R. B., Maher, C., \& Noddings, N. (Eds.).(1990) Constructivist views on teaching and learning mathematics (pp. 125-146), Journal for Research in Mathematics Teacher Education, Monograph Series, No. 4. Reston, VA: National Council of Teachers of Mathematics.

Dawson, S. (1999). The enactive perspective in teacher development: 'A path laid while walking'. In B. Jaworski, T Wood, \& S. Dawson (Eds.), Mathematics teacher education: Critical international perspectives (pp. 148-162). London: Falmer Press.

Forman, E., \& Ansell, E. (2001). The multiple voices of a mathematics classroom community. Educational Studies in Mathematics, 46, 115-142.

Glasersfeld, von E. (1987). Learning as a constructive activity. In C. Janvier (Ed.), Problems of representation in the teaching and learning of mathematics (pp. 3-17). Hillsdale, NJ: Lawrence Erlbaum.

Goos, M., Galbraith, P., \& Renshaw, P. (1990). Establishing a community of practice in a secondary mathematics classroom. In L. Burton (Ed.), Learning mathematics: From hierarchies to networks (pp. 36-61). London: Falmer Press.

Irwin, K. C., \& Britt, M. S. (1999). Teachers' knowledge of mathematics and reflective professional development. In B. Jaworski, T Wood, \& S. Dawson (Eds.), Mathematics teacher education: Critical international perspectives (pp. 91-101). London: Falmer Press.

Jaworski, B., \& Wood, T. (1999). Themes and issues in inservice programmes. In B. Jaworski, T Wood, \& S. Dawson (Eds.), Mathematics teacher education: Critical international perspectives (pp. 125147). London: Falmer Press.

Jaworski, B., Wood, T., \& Dawson, S. (1999). Mathematics teacher education: Critical international perspectives. London: Falmer Press.

Kelly, A (Ed.) (2003). Theme issue: The role of design in educational research. Educational Researcher, 32.

Krainer, K. (2006). How can schools put mathematics in their centre? Improvement $=$ content + community + context. In J. Novotná, H. Moraová, M. Krátká, \& N. Stehliková (Eds.), Proceedings of the 30th Conference of the International Group for the Psychology of Mathematics Education (Vol. 1, pp. 84-89). Prague, Czech Republic: Charles University.

Lachance, A., \& Confrey, J. (2003). Interconnecting content and community: A qualitative study of secondary mathematics teachers. Journal of Mathematics Teacher Education, 6, 107-137.

Lerman, S. (1996). Intersubjectivity in mathematics learning: A challenge to the radical constructivist paradigm? Journal for Research in Mathematics Education, 27, pp. 133-150.

Potari, D., \& Jaworski, B. (2002). Tackling complexity in mathematics teaching development: Using the teaching triad as a tool for reflection and analysis. Journal of Mathematics Teacher Education, 4, $351-380$. 
MATHEMATICS TEACHER EDUCATOR LEARNING

Serrazina, L., \& Loureiro, C. (1999). Primary teachers and the using of materials in problem solving in Portugal. In B. Jaworski, T Wood, \& S. Dawson (Eds.), Mathematics teacher education: Critical international perspectives (pp. 49-58). London: Falmer Press.

Steffe, L. P., \& Thompson, P. W. (2000). Interaction or intersubjectivity? A reply to Lerman. Journal for Research in Mathematics Education, 31, 191-209.

Steinbring, H. (1998). Elements of epistemological knowledge for mathematics teachers. Journal of Mathematics Teacher Education, 1, 157-189.

Vital, R., \& Valero, P. (2003). Researching mathematics education in situations of social and political conflict. In A. J. Bishop, M.A. Clements, C. Keitel, J Kilpatrick, F. K. S. Leung (Eds.), Second international handbook of mathematics education (pp. 545-592). Dordrecht, The Netherlands: Kluwer Academic..

Wood, T. \& Berry, B. (2003). What does „Design Research“ offer mathematics teacher education? Journal of Mathematics Teacher Education, 6, 3, pp 195-199.

Zevenbergen, R. (2001). Language, social class and underachievement in school mathematics. In P. Gates (Ed.), Issues in mathematics teaching (pp. 38-50). London: Routledge/Falmer.

Barbara Jaworski

Mathematics Education Centre

Loughborough University 